\title{
O espaço da clínica
}

The space for clinical practice

\section{Tum Ta Tum $\mathrm{Ta}$ Tum $\mathrm{Ta}$ Tum $\mathrm{Ta}$ Tum}

Tum Ta Tum Ta Tum Ta Tum Ta Tum Ta Tum
TumTumTumTumTumTumTumTumTumTumTumTumTum...

O coração acelera, se faz sentir, ganha corpo. Invade brutalmente a vida que vivia simplesmente, e chama a seu serviço a pele que esfria, o suor que encharca e o tremor que abala. $\mathrm{O}$ ar, que como o coração parecia não existir, amotina-se e torna-se espesso, lento, exigindo um grande esforço para servir a seu propósito. Medo, pavor, pânico, vários nomes acorrem tentando, em vão, acalmar o corpo em revolta. A morte, a imagem da morte vem logo em socorro. Ah! Então é isso, estou morrendo! Nem a morte, no entanto, é guarida. Não se trata de morrer, mas sim de viver. O coração se apresenta vivo, sem pedir licença! O estranho arromba a porta, toma corpo. Não é um inimigo a ser atacado pura e simplesmente, mas é impossível conviver com tal presença. O corpo é o duplo aterrador e inapreensível do eu. Esse estranho coração que bate, este estranho ar que penetra! "Doutor, o que é isso?!?!”

${ }^{1}$ Médico e psicanalista; Doutorando em Psicologia Clínica na Pontifícia Universidade Católica, PUC-SP (Núcleo Subjetividades Contemporâneas).<aragonn@uol.com.br> 
Essa situação paradoxal é freqüente no consultório do cardiologista. O corpo se apresenta como estranho, como irrepresentável e, em um esforço tranqüilizador, como perseguidor.

"Respire fundo, diga trinta-e-três, faça estes exames". São atitudes médicas, na certeza de encontrar a lesão que produz tão angustiante sensação. Ah! Só quem é médico sabe a sensação de encontrar uma lesão! Uma delicia! Prazer obviamente dissimulado por uma consternação compartilhada com o paciente. Não seria necessário contornar a alegria do diagnóstico, pois neste quesito o paciente é um aliado, "agora eu entendo, sou cardíaco". Será que o resto do mundo não é?

Para infelicidade do profissional e do paciente, este encontro angústia/ lesão nem sempre acontece, $e$ arriscaria dizer, os desencontros têm sido cada vez mais freqüentes.

Dentre tantas classificações possíveis, miocardiopatia, prolapso da valva mitral, extrassistolia, fibrilação atrial, e tantas outras, essa "coisa" insiste em se furtar. Não há duvida, estamos diante de um "paciente difícil". É uma dificuldade só, o paciente, o sintoma, o diagnóstico, o médico.

No consultório de Psicanálise, curiosamente, encontramos, aqui também, esta estranha figura, o "paciente difícil". Limítrofe e borderline, entre outros nomes, são também utilizados para designar esse personagem mítico que insiste em assombrar. Nomes que desesperadamente buscam colocar em algum lugar, em alguma ordenação, este existir acompanhado de tanta angústia.

Uma "dificuldade" destas entrou outro dia em meu consultório (de Psicanálise). Tinha na época 17 anos e veio após contato telefônico do pai. Não sabia porque estava ali, e falava sem parar assuntos diversos. Começo a perceber nele, e também em mim, uma tensão crescente. As narrativas se sucedem num ritmo apressado, sem um nexo consistente, com uma monotonia afetiva que resiste a toda variação dos assuntos. Todavia, a velocidade mesma da fala deixa entrever uma angústia crescente. Acorre-me um receio de que as palavras acabem. Por algum motivo me invade a sensação de que algo catastrófico vai ocorrer se aquele fluxo interromper. Assuntos alegres, tristes, descrição de inúmeros projetos claramente intercambiáveis e sem nenhum sentido identificável entre eles, desfilam à minha frente. É um discurso que não comunica um conteúdo, não faz pausas, não respira. Uma fala - nestas horas é que se percebe - tem um ritmo, faz dobras, suspense, cria atalhos e prolonga certos caminhos. Uma fala encarna histórias, de alegria, de tristeza, de ironia, de compaixão, de ... . São emoções que acompanham imagens, e vice-versa, tecendo uma rede interminável à medida que as imagens mudam e as emoções também. Mas no encontro a que me referia não há cadência, textura, colorido. Existe, sim, uma urgência, um perigo. Perigo este precipitado pelo encontro, mas relação tornada impossível - ou melhor, difícil - pelo que parece ser uma luta pela sobrevivência.

Qual a relação possível com uma pessoa que parece estar (e talvez esteja) na iminência de uma catástrofe?

O encontro acontece na angústia, na urgência de uma palavra milagrosa, na respiração suspensa. Essa é a atmosfera possível, que ocupa todos os 
espaços, criando a experiência de um ser espesso, ameaçador, onipresente.

São sensações subjetivas, que acompanham situações vividas em consultório. Reparo que, com apresentações diferentes, alguns ingredientes destes que descrevo vêm se repetindo, principalmente - mas não só - em jovens.

A aproximação de experiências cardiológicas e psicanalíticas, tendo o consultório como ponto de ligação, é especialmente feliz, no sentido de destacar o campo subjetivo que, longe de separar, inclui o psíquico e o somático. As pessoas vivem em todo o seu ser o impacto das mudanças do mundo contemporâneo.

Vai-se delineando, então, a questão que julgo ser importante ter em mente no espaço da clínica. Quando da procura por ajuda, todo o ser está em sofrimento. É o coração que revela a perda recente, a depressão que protege de uma dor maior, o suspiro que busca ganhar fôlego para enfrentar um inimigo muitas vezes desconhecido.

Esta concepção de clínica implica perceber o sujeito que sofre em total interação com o mundo no qual está inserido. Com suas tristezas e alegrias, revela seu eu mais íntimo, revelando e afetando, assim, o entorno. Caminhos da angústia como o pânico, a depressão, a drogadição, a confusão, os sintomas corporais sem lesões aparentes, são apresentações que não devem ser encarceradas em classificações estanques. Isto sob pena de não se poder acolher a emergência do novo de nossos tempos.

A vida das pessoas que procuram um clínico (em sentido lato) é muito mais complexa e rica do que a possibilidade que temos de nomear o seu sofrimento. O que estou chamando de espaço da clínica, então, consiste em um lugar - não geográfico - de expressão daquilo que é "difícil", do que não tem nome, mas afeta, alegra e entristece. Quando temos a felicidade de viver neste espaço, muitas vezes percebemos que a doença é na verdade aquilo que mais pode produzir mudança. É um grito da vida, que busca um caminho para se realizar.

Trata-se de uma reflexão sobre o significado da clínica como espaço de relações, em que o paciente comparece em sua totalidade.

PALAVRAS-CHAVE: Ética médica; clínica, relações médico-paciente. KEY WORDS: Medical ethics; clinics; physician-patient relations.

PALABRAS CLAVE: Ética medica; clinica; relaciones medico-paciente. 
"Vamos ouvir esse silêncio meu amor amplificado no amplificador do estetoscópio do doutor no lado esquerdo do peito esse tambor"

Arnaldo Antunes

(Fragmento d'O Silêncio) 